\title{
O SISTEMA DE SEGURIDADE SOCIAL BRASILEIRO
}

Zélia Luiza Pierdoná

Professora dos cursos de graduação e pós-graduação da Faculdade de Direito da Universidade Presbiteriana Mackenzie; Mestre e Doutora em Direito pela PUC/SP; realizou estágio pós-doutoral na Universidade Complutense de Madri (Bolsista da CAPES); Coordena o grupo de pesquisa ativismo judicial e seguridade social; também é Procuradora Regional da República.

\section{Resumo}

O presente trabalho tem por objetivo apresentar as normas constitucionais relacionadas à seguridade social brasileira, para demonstrar que a Constituição criou um sistema de proteção social e não áreas isoladas, como tem sido tratado pelo Estado brasileiro, em suas três funçóes: legislativa, executiva e judiciária. Nesse sentido, as normas constitucionais diretamente relacionadas à seguridade social estão nos arts. 194 a 204 e 40 da Constituição, nos quais são enunciadas as diretrizes fundamentais: os princípios aplicáveis e a forma de seu financiamento (arts. 194 e 195), as áreas componentes e a estrutura de cada uma delas (saúde - arts. 196-200; previdência - arts. 201, 202 e 40; e assistência - arts. 203 e 204).

\section{Palavras-chave}

Seguridade social; Áreas componentes; Princípios aplicáveis; Responsabilidade dos entes federativos.

\section{Resumen}

Este estudio tiene como objetivo presentar las normas constitucionales relativas a la seguridad social brasileña, para demostrar que la Constitución brasileña creó un sistema de protección social, y no áreas aisladas, como ha sido tratado por el gobierno brasileño en sus tres funciones: legislativa, ejecutiva y judicial. En este sentido, las normas constitucionales relacionadas directamente con la seguridad social están en los artículos 194-204 y 40 de la Constitución, en los que se establecen las directrices fundamentales: los principios aplicables y la forma de financiación (artículos 194 y 195), las áreas componentes y la estructura de cada una de ellas (la salud - artículos 196-200; la previsión social - artículos 201, 202 y 40; y la asistencia - artículos 203 y 204). 


\section{Palabras clave}

Seguridad social; Áreas componentes; Principios; La responsabilidad de los entes federales.

\section{Introdução}

A Constituição brasileira de 1988 criou um sistema de proteção social e o designou seguridade social, o qual tem por objetivo proteger a todos nas situaçóes de necessidades. Para tanto, uniu três direitos sociais, os quais têm área específica de atuação e destinatários delimitados, mas que no conjunto abrange todos os necessitados.

Para garantir a efetividade da citada proteção, estabeleceu um sistema amplo de financiamento, o qual se dá de forma direta e indireta, por toda a sociedade. Além disso, determinou a competência administrativa e legislativa dos entes federativos, em relação a cada um dos subsistemas.

O trabalho que segue tem por objetivo apresentar, de forma sintética, as disposiçóes constitucionais do mencionado sistema. Para tanto, num primeiro momento, serão elencados os preceitos constitucionais comuns a todo o sistema, ou seja, as disposiçóes que são aplicadas as três áreas, especialmente os princípios específicos da seguridade social. Posteriormente, serão feitas breves considerações sobre o seu financiamento e, por fim, apresentadas as disposiçóes constitucionais de cada um dos subsistemas: saúde, previdência e assistência social.

\section{Delimitação Constitucional da Seguridade Social Brasileira}

$\mathrm{O}$ art. 194 da Constituição estabelece que a "seguridade social compreende um conjunto integrado de açóes de iniciativa dos Poderes Públicos e da sociedade, destinadas a assegurar os direitos relativos à saúde, à previdência e à assistência social”. Assim, para o Brasil, o termo seguridade social compreende o conjunto que abrange três direitos sociais, os quais, apesar de possuírem área específica de atuação e destinatários predeterminados, compóem um sistema com características comuns.

Além disso, verifica-se, pelo texto constitucional transcrito, que a responsabilidade pela sua efetivação não é exclusiva do Estado, já que as ações são de iniciativa dos Poderes Públicos e da sociedade. Portanto, o sistema de seguridade social também compreende a proteção privada, a qual se dá nas três áreas que compóem o conjunto de proteção.

O parágrafo único do referido artigo constitucional estabelece os princípios específicos aplicáveis à proteção social, para o qual devem ser acrescentados o caput do art. $195 \mathrm{e}$ seu $\$ 5^{\circ}$. O art. 195 preceitua, ainda, os meios para garantir a efetivação, já que estabelece as formas de financiamento. 
Portanto, pode-se afirmar que os arts. 194 e 195 da Constituição estabelecem as normas aplicáveis às três áreas componentes da seguridade social. É justamente a partir de seus preceitos que se verifica a necessidade de se compreender a proteçáo social como um conjunto integrado de ações, nos dizeres da Constituição, e não em três áreas isoladas, como tem sido concebido pelo Estado brasileiro em suas três funçóes: executiva, legislativa e judiciária.

Justamente em razão dessa compreensão isolada e não de conjunto, tem-se verificado incoerências que, a partir de uma concepção de sistema, poderão ser eliminadas ou, ao menos, amenizadas.

Para tanto, inicialmente deve-se conhecer as normas que são destinadas às três áreas e, a partir delas, compreender os preceitos destinados especificamente a cada uma de suas subáreas: saúde (arts. 196-200); previdência (arts. 201, 202 e 40); e assistência (arts. 203 e 204).

Nesse sentido, o parágrafo único do art. 194 estabelece que compete ao Poder Público organizar a seguridade social. Para tanto, deverá observar os princípios elencados no próprio dispositivo constitucional, bem como no caput do art. 195 e seu $\$ 5^{\circ}$.

\section{Princípios da Seguridade Social}

Abaixo serão apresentados os princípios específicos do sistema de seguridade social.

\section{Universalidade da Cobertura e do Atendimento}

O inciso I, do preceito constitucional acima referido, estabelece o princípio da universalidade da cobertura e do atendimento. Isso significa que todos os cidadãos brasileiros são destinatários de proteção social.

Porém, isso não significa que a proteção é de responsabilidade apenas do Estado. Isso porque, conforme disposição do caput do art. 194, já referido, as açóes são de iniciativa dos Poderes Públicos e da sociedade. Assim, tanto o Estado quanto a sociedade devem garantir a todos, ao menos, condiçóes mínimas ${ }^{1}$ de vida $^{2}$.

1 Isso não significa que toda a seguridade social tem por objetivo garantir apenas o mínimo para a sobrevivência. Isso porque, uma de suas áreas - a previdência - tem por objetivo substituir os rendimentos do trabalho, os quais, muitas vezes, garantem além do mínimo. A mencionada forma de proteção, como se verificará no presente trabalho, depende de prévio recolhimento de contribuiçōes. Por outro lado, a assistência social visa garantir o mínimo e é concedida independentemente de contribuição ao sistema.

2 Visando estabelecer um padrão (um piso) mínimo de proteção social, a Conferência Geral da Organização Internacional do Trabalho - OIT editou, em 14-06-2012, a Recomendação 202, conhecida como a "Recomendação Relativa aos Pisos de Proteção Social". in http://www.ilo.org/public/spanish/protection/secsoc/downloads/policy/policy2s.pdf). Acesso em 04-06-2015. 
O princípio, ora em análise, estabelece a universalidade da cobertura e do atendimento. Àquela corresponde as situaçôes de necessidade que são objeto de proteção. À universalidade do atendimento, por sua vez, corresponde aos destinatários das prestaçóes de seguridade social.

Importante ressaltar que a universalidade não pode ser compreendida em relação a cada uma das áreas componentes da proteção social isoladamente, mas deve ser entendida no sistema de seguridade social como um conjunto.

Nesse aspecto, verifica-se que o sistema de proteção social criado na Constituiçáo de 1988 apresenta duas faces: em uma delas tem-se a saúde, que foi universalizada, nos termos do art. 196. Antes de 1988, a saúde era dirigida apenas aos trabalhadores e seus dependentes e não a todos os cidadãos. Seguindo a recomendação do Relatório Beverid$\mathrm{ge}^{3}$, a atual Constituição estendeu o acesso à saúde a todos.

$\mathrm{Na}$ outra face, a seguridade social apresenta duas subdivisóes: a previdência e a assistência. Ambas tem seu aspecto subjetivo de proteção limitados: a previdência dirige-se aos trabalhadores e seus dependentes e a assistência aos necessitados. Nem todos são trabalhadores e/ou dependentes de trabalhadores e nem todos são necessitados. Assim, apenas unindo as duas subáreas tem-se a possibilidade de garantir a universalidade.

Importante ressaltar ainda que a universalidade é um vir a ser. Isso porque, somente haverá a universalidade quando todos os cidadãos e todas as situaçóes de necessidade tiverem cobertura. No caminho da universalidade deverá ser feita a seletividade, conforme prevê o art. 194, parágrafo único, III, da Constituição.

\section{Seletividade e Distributividade na Prestação dos Benefícios e Serviços}

Considerando que o princípio da universalidade corresponde a um vir a ser, rumo a sua efetivação, deve-se selecionar etapas a serem cumpridas, ou seja, devem ser selecionadas as pessoas e as situaçóes que terão prioridade de atendimento e cobertura. Assim, o princípio da seletividade revela uma contenção provisória da universalidade. No caminho de sua efetivação, o legislador e o executivo, cada um dentro de sua área de atribuição, deverão selecionar as necessidades que serão atendidas.

Há que se ressaltar que a seleção, apesar de discricionária, deve seguir as diretrizes constitucionais, dentre as quais o segundo mandamento do princípio ora em análise, que é a distributividade. Nesse aspecto, entende-se que a seleção deve ser efetuada considerando a justiça e o bem estar social, que são elencados como objetivos da ordem social,

3 BEVERIDGE, William. Seguro social y servicios afines: informe de Lord Beveridge, Madrid, Centro de Publicaciones del Ministerio de Trabajo y Seguridad Social, 1989. 
no art. 193 da Constituição. Na medida em que se busca a efetivação de tais objetivos, se garante também a efetivação dos objetivos do Estado brasileiro, previstos no art. $3^{\circ}$, também da Constituição, especialmente os elencados nos incisos I e III, respectivamente, a construção de uma sociedade livre, justa e solidária; e a erradicação da pobreza e da marginalização e a redução das desigualdades sociais e regionais.

Há outras diretrizes constitucionais que devem ser observadas pelo legislador e pelo executivo, quando da seleção, as quais estão previstas nas disposiçóes específicas de cada uma das subáreas componentes da seguridade social. Nesse sentido, o art. 198, II, da Constituição, ao tratar da saúde, prioriza as atividades preventivas. Em relação à previdência, o art. 201 estabelece os eventos causadores de necessidades que devem ter cobertura pelo Regime Geral de Previdência Social, o qual também se aplica aos Regimes dos Servidores Públicos, haja vista o enunciado do $\$ 12$ do art. 40, todos da Constituição. Quanto à assistência social, o caput do art. 203 estabelece que esta subárea da seguridade social visa atender aos necessitados. Com isso, devem ter prioridade de atendimento os mais necessitados.

Dessa forma, o princípio em comento permite que as pessoas e situaçóes sejam tratadas de forma desigual pois, se a sociedade é desigual e, se o art. $3^{\circ}$ da Constituição estabelece como objetivo do Estado, dentre outros, o da redução das desigualdades sociais, apenas um tratamento desigual será adequado para a mencionada redução. Nesse sentido, Paulo Bonavides ${ }^{4}$, citando Robert Alexy, assevera que "quem quiser produzir a igualdade fática, deve aceitar por inevitável a desigualdade jurídica”.

Importante ressaltar que a seleção deve ser feita pelo Poder Legislativo e Executivo, cada um dentro de sua área respectiva. E, estando a seleção conforme a Constituição, deve ela ser respeitada pelo Poder Judiciário, o qual somente poderá afastá-la se a escolha feita não encontra fundamento de validade no texto constitucional. Em relação a isso, observa-se que, muitas vezes, o Poder Judiciário tem feito outras seleçóes, substituindo, indevidamente, os demais poderes. Inclusive a escolha feita pelo Poder Judiciário tem se utilizado de preceitos isolados da Constituição e não de uma análise sistemática dos preceitos constitucionais relacionados à seguridade social.

\section{Uniformidade e Equivalência das Prestações às Populações Urbanas e Rurais}

O princípio, ora em análise, tem por objetivo afastar o tratamento inferior que era concedido às populaçóes rurais.

4 BONAVIDES, Paulo, Curso de Direito Constitucional, 23a ed. São Paulo, Malheiros Editores, 2008, p. 378. 
Exemplo disso era a proteção previdenciária, na qual o trabalhador rural tinha uma proteção inferior àquela concedida aos urbanos (o valor da aposentadoria correspondia a $50 \%$ do salário-mínimo e, o da pensão, inicialmente era de $30 \%{ }^{5}$, tendo passado a ser de 50\%, a partir da Lei Complementar no 16/73 ).

Também em relação à saúde o tratamento era diverso. Enquanto os trabalhadores urbanos tinham acesso à saúde, os rurais ficavam na dependência de recursos e, além disso, poderia haver a cobrança do usuário, conforme se pode observar no preceito do art. 12 da LC no 11/71: "Os serviços de saúde serão prestados aos beneficiários, na escala que permitirem os recursos orçamentários do FUNRURAL, em regime de gratuidade total ou parcial segundo a renda familiar do trabalhador ou dependente".

Assim, o princípio da uniformidade e equivalência dos benefícios e serviços às populações urbanas e rurais busca exatamente eliminar essas diferenças. A partir da Constituição de 1988, a saúde não é mais dirigida apenas aos trabalhadores e seus dependentes, mas a todos os cidadãos, independente do execício profissional ou mesmo de sua classificação. Isso ocorre também nas outras duas subáreas da seguridade social.

A única diferença estabelecida na própria Constituição refere-se ao segurado especial, prevista no art. $195, \$ 8^{\circ}$, o qual preceitua uma forma diferente de contribuição e, consequentemente, também permite uma desigualação na proteção, já que menciona que os benefícios serão estabelecidos "nos termos da lei". Isso se deve ao segundo mandamento do princípio, "equivalência dos benefícios e serviços". Portanto, se a forma de contribuição é diversa, a proteção deve ter equivalência, e, com isso, também ser diversa. Nesse sentido, a legislaçấo infraconstitucional estabeleceu que os benefícios devidos ao segurado especial equivalem a um salário-mínimo, independente do valor da contribuição.

Aos demais trabalhadores rurais (empregados, contribuintes individuais e avulsos) não há qualquer diferença, tanto em relação ao custeio, quanto no que tange aos benefícios. A única diferença se refere à redução de 5 anos, no caso de aposentadoria por idade, a qual foi estabelecida na própria Constituição, na parte final do inciso II do $\$ 7^{\circ}$ do art. 201.

\section{Irredutibilidade do Valor dos Benefícios}

O princípio da irredutibilidade do valor dos benefícios aplica-se às subáreas previdência e assistência social, uma vez que na saúde tem-se apenas serviços e não benefícios (prestaçóes em dinheiro).

Irredutibilidade significa manter o valor nominal. Assim, um benefício de aposentadoria (previdência social), por exemplo, de $\mathrm{R} \$ 1.000,00$ náo pode ser reduzido

5 Arts. $4^{\circ}$ e $6^{\circ}$ da Lei Complementar no $11 / 71$ e art. $6^{\circ}$ da Lei Complementar no 16/71. 
a R \$ 950,00. Também um benefício de bolsa família (assistência social) no valor, por exemplo, R\$100,00, náo pode ser reduzido para $\mathrm{R} \$ 95,00$.

O referido princípio também se aplica aos trabalhadores em atividade, conforme o preceito do inciso VI do art. $7^{\circ}$ da Constituição: "irredutibilidade do salário, salvo o disposto em convenção ou acordo coletivo”.

Importante mencionar que o princípio em comento não garante a manutenção do valor real. A citada manutenção é garantida apenas aos benefícios previdenciários, uma vez que decorre do preceito do $\$ 4^{\circ}$ do art. 201 da Constituição ${ }^{6}$, o qual trata da previdência social e não de toda a seguridade social, como ocorre com o art. 194. O mencionado preceito constitucional relaciona-se ao poder aquisitivo, que deve ser observado no reajustamento dos benefícios apenas da previdência social.

Assim, os benefícios da assistência social não precisam ser obrigatoriamente reajustados para garantir a manutenção do valor real. Ressalta-se que o de prestação continuada, a que se refere o art. 203, V, da Constituição, está atrelado ao salário-mínimo, em razão do citado dispositivo constitucional e, portanto, seus reajustes não estáo vinculados a manutenção do valor real.

Verifica-se, dessa forma, que a manutenção do valor real é dirigida apenas a previdência social e não a toda a seguridade social. Por outro lado, a irredutibilidade do valor dos benefícios é dirigida a todas as áreas da seguridade social para as quais tem aplicabilidade, ou seja, que possuem benefícios (previdência e assistência social).

\section{Equidade na Forma de Participação no Custeio}

$\mathrm{O}$ art. 195 da Constituição determina que a seguridade social deve ser financiada por toda a sociedade, de forma direta e indireta. E, o princípio em comento, estabelece que a participação no custeio deve ser de forma equânime.

Assim, a primeira pergunta que se apresenta é se equidade deve ser entendida como sinônimo de capacidade contributiva, a qual é aplicada, por expressa disposição constitucional, aos impostos (art. $145, \$ 1^{\circ}$ da Constituição). A resposta a citada pergunta é

6 Art. 201. "A previdência social será organizada sob a forma de regime geral, de caráter contributivo e de filiação obrigatória, observados critérios que preservem o equilíbrio financeiro e atuarial, e atenderá, nos termos da lei, a:

(...)

$\$ 4^{\circ}$ É assegurado o reajustamento dos benefícios para preservar-lhes, em caráter permanente, o valor real, conforme critérios definidos em lei".

É importante mencionar que os critérios são fixados em lei, a qual não está atrelada aos reajustes concedidos ao salário-mínimo. A única exigência constitucional é a necessidade de preservaçăo do valor real, ou seja, deve ser reposta a inflação do período. 
negativa, uma vez que, embora a capacidade contributiva também deva ser considerada para se determinar a equidade, esta é muito mais ampla e deve levar em conta as formas de financiamento, assim como, a finalidade das contribuiçóes, as quais fazem parte da forma direta de financiamento.

Isso porque, as contribuições previstas no art. 149 da Constituição, nas quais se incluem as de seguridade social (art. 195, também da Constituição), se diferenciam das demais espécies tributárias pelas suas finalidades constitucionais.

E, quanto à finalidade das contribuiçóes, o princípio da equidade permite que se observe, por exemplo, a relação entre a contribuição e as prestaçôes, ou seja, deve ser considerado o risco que o sujeito passivo produz para o sistema de seguridade social. Este é o caso da contribuiçáo prevista no art. 22, II, da Lei 8.212/91, cujas alíquotas variam de 1 , 2 a 3\%, conforme o risco apresentado pelo contribuinte (leve, médio ou grave), segundo a atividade econômica em que se enquadra. As referidas alíquotas podem ser reduzidas em 50\% ou acrescentadas em 100\%, conforme prevê o art. 10 da Lei 10.666/2003, em razão do desempenho da empresa em relação à respectiva atividade econômica. Pode-se citar, também, o acréscimo para o financiamento das aposentadorias especiais (art. 57, $\$ 6^{\circ}$, da Lei 8.213/91).

Outra especificidade que também pode ser observada é a utilização da mão-de-obra. Dessa forma, as atividades mais informatizadas poderiam ter alíquotas superiores àquelas que empregam mais pessoas. Isso não deixa de ser um aspecto relacionado à produção de riscos, acima comentado, já que as as atividades mais informatizadas contribuem para o aumento do risco previsto no art. 201, III, da Constituição- desemprego involuntário.

Mas a equidade também comporta a apreciação da capacidade contributiva do sujeito passivo da obrigação, embora, como já referido, não seja sinônimo. Exemplo disso é a adoção de diferentes alíquotas, em relação aos segurados da previdência social: empregados, empregados domésticos e avulsos (8, 9 ou 11\%), contribuintes individuais (20, 11 ou $5 \%$ ).

$\mathrm{O}$ art. 195 , em seu $\$ 9^{\circ}$ preceituou que as alíquotas e as bases de cálculo das contribuiçóes da empresa podem ser diferenciadas, "em razão da atividade econômica, da utilização intensiva de mão-de-obra, do porte da empresa ou da condição estrutural do mercado de trabalho", demonstrando aspectos do princípio da equidade.

Além dos aspectos acima tratados, relacionados às contribuiçóes, o princípio, ora analisado, permite a cobrança de valores diretamente dos usuários das prestaçôes de seguridade social, na medida de sua própria renda ou de sua família. Isso porque, se o Estado brasileiro tem como um de seus objetivos a redução das desigualdades sociais, a gratuidade das prestaçóes de saúde a todos, por exemplo, independente dos rendimentos dos destinatários, aumentará as desigualdades e não as reduzirá. 
Em relação ao exemplo acima, deve ser ressaltado que é a legislação infraconstitucional que estabelece a gratuidade das prestaçóes do Sistema Único de Saúde - SUS (Lei no 8.080/90). Entretanto, para dar efetividade ao princípio da equidade na forma de participação do custeio e, dessa forma, buscar reduzir as desigualdades sociais, talvez o mais adequado seria a instituição da cobrança de valores, segundo a capacidade econômica dos usuários e as contingências cobertas. Para tanto, a legislaçáo deverá ser alterada, eliminando-se a gratuidade.

\section{Diversidade da Base de Financiamento}

O constituinte, além de ter criado um sistema amplo de proteção social, o qual visa proteger a todos, em todas as situaçóes de necessidade, criou meios para garantir a sua efetivaçáo, na medida que determinou a ampliação de seu custeio, estabelecendo a exigência de diversas bases para o financiamento da seguridade social.

No sistema anterior, a principal base de financiamento era a contribuição sobre os rendimentos do trabalho, a qual incidia tanto para o trabalhador, quanto para aquele que utilizava seus serviços (empregador).

A Constituição, além de ter criado o princípio ora analisado, estabeleceu os pressupostos de diversas bases de cálculo para as contribuições, nos incisos do art. 195, bem como no art. 239, no qual recepcionou as contribuiçôes do PIS/PASEP e as destinou também à seguridade social, mais especificamente à previdência social (art. 201, III, da Constituição). Além disso, no $\$ 4^{\circ}$ do art. 195 permitiu a criação de novas fontes.

Também, o princípio em comento, permite que o financiamento se dê por meio da participação direta dos usuários dos serviços de seguridade social, conforme referido no princípio da equidade na forma de participação do custeio, a exemplo do que ocorre em Portugal (taxas moderadoras) e na Espanha (coparticipação do usuário).

O principal objetivo do princípio da diversidade da base de financiamento é garantir a efetividade da proteção social. Entretanto, a diversidade também permite a universalidade do custeio, a qual está expressamente prevista no caput do art. 195, quando preceitua que toda a sociedade financiará a seguridade social.

\section{Gestão da Seguridade Social}

$\mathrm{O}$ art. 194, parágrafo único, VII, da Constituição prevê que a gestão da seguridade social deve ter caráter democrático e descentralizado.

Em relação ao caráter democrático, tem-se que a gestão deve ter a participação dos destinatários da proteção. Entretanto, é necessário ressaltar que a redação do citado preceito 
constitucional revela a falta de noção do sistema de proteção social, inclusive pelo constituinte, em especial o da EC no 20/98.

Isso porque, a redação original, embora tenha cometido um equívoco ao mencionar "em especial de trabalhadores, empresários e aposentados", referia-se a participação da comunidade, na qual pode-se entender a participação dos destinatários de cada uma das subáreas componentes da seguridade social. Diz-se equivoco quando utilizou "em especial de trabalhadores, empresários e aposentados", pois eles estão relacionados à previdência social e não a toda a seguridade social. Mas, de qualquer forma, o termo "comunidade" atendia as outras duas subáreas (saúde e assistência).

A EC no 20/98 eliminou a pouca noção de sistema que o dispositivo continha, uma vez que retirou o termo "comunidade", tendo estabelecido a seguinte redação: "caráter democrático e descentralizado da administração, mediante gestão quadripartite, com participação dos trabalhadores, dos empregadores, dos aposentados e do Governo nos órgão colegiados". A gestão quadripartite revela o caráter democrático, mas apenas da previdência social e o artigo 194 está tratando de todo o sistema e não de apenas parte dele. O referido equivoco obrigou que nas disposiçôes específicas de saúde (art. 198, III) e de assistência (art. 204 (204, II) o tema voltasse a ser tratado.

Com isso, verifica-se que a falta de visão de conjunto do sistema de seguridade social é mais grave do que parece, já que não se limita ao ordenamento infraconstitucional.

O caráter democrático pode ser observado, por exemplo, na participação dos beneficiários nos conselhos de cada uma das subáreas, os quais foram criados pelas Leis $n^{\circ}$ 8.080/90 (saúde), no 8.213/91 (previdência social) e no 8.742/93 (assistência social).

O caráter descentralizado da gestão está relacionado à forma federativa de Estado, prevista no art. $1^{\circ}$ da Constituição. Isso significa que os diferentes entes federativos terão participaçóes diversas, principalmente considerando a proximidade em relação ao beneficiário. Isso se dá especialmente em relação à saúde e à assistência social, já que as duas subáreas são de atribuição comum de todos os entes da federação, conforme previsto no art. 23, II, da Constituição, o que não se dá com a previdência social, especialmente com o Regime Geral de Previdência Social, o qual é de atribuição exclusiva da União. Os demais entes federativos cuidam apenas da previdência de seus servidores titulares de cargos efetivos.

No que tange a este aspecto da gestão (descentralizaçáo), inicialmente se sustentava que estava relacionado à administração pública indireta, ou seja, que sua execução, tanto em relação às prestaçóes, quanto à cobrança das contribuiçóes, não poderia ser feita pela administração direta. $\mathrm{O}$ referido entendimento foi afastado pelo Supremo Tribunal Federal, no RE 146.733-9, e, a partir da criação da Receita Federal do Brasil, todas as contribuiçóes de seguridade social são arrecadadas pelo referido órgáo. $\mathrm{O}$ mencionado 
entendimento é fruto de uma visão baseada no sistema de proteção anterior à Constituição de 1988, no qual a previdência e a saúde eram dirigidas a parte da população e eram executadas pela Administração Indireta (INPS, INAMPS, IAPAS).

\section{Custeio Prévio}

$\mathrm{O}$ art. $195, \$ 5^{\circ}$, da Constituição estabelece que "nenhum benefício ou serviço da seguridade social poderá ser criado, majorado ou estendido sem a correspondente fonte de custeio total". Com isso, garante-se a efetivação da proteção, uma vez que sem custeio não há que se falar em proteção.

O princípio do custeio prévio tem por objetivo revelar a decisão política de ampliar ou não o sistema protetivo, aliado à capacidade de financiamento da sociedade relacionada à proteção social.

Apesar do preceito, verifica-se que muitas leis majoram a proteção e não fazem qualquer referência às formas de custeio. Exemplo disso é a lei que instituiu o Estatuto do Idoso, a qual determinou que o benefício de prestação continuada da assistencial social (art. 203, V, da Constituição), concedido a um idoso, não deve compor a renda familiar per capita para a concessão do citado benefício a outro idoso. Assim houve a extensáo de um benefício sem a correspondente fonte de custeio.

Também as decisões judiciais que ampliam a proteção sempre violam o citado princípio, já que o custeio advém de tributos e, nos termos do art. 150, I, da Constituição, apenas por meio de lei eles podem ser instituídos. Exemplo de decisão judicial que amplia a proteção, ficando no mesmo benefício mencionado no parágrafo anterior, é a decisão do STF, que determinou que fosse afastado os benefícios previdenciários no valor de um salário mínimo e, também, o benefício assistencial devido ao deficiente, já que o Estatuto do Idoso determinava que se afastasse apenas o beneficio assistencial devido ao idoso. Além disso, o mesmo tribunal entendeu que o juiz, no caso concreto, poderá estabelecer outro critério de miserabilidade para efeitos de concessão da prestação, que não aquele previsto na Lei Orgânica da Assistência Social (1/4 de salário mínimo). Com isso, houve uma majoração de um benefício, via Poder Judiciário, sem a correspondente fonte de custeio.

O princípio em comento tem por objetivo evitar medidas demagógicas, já que o aumento de uma prestação social pode inclusive trazer vantagens eleitorais, quer a um membro do Poder Legislativo, quer a um titular de cargo no Poder Executivo. Assim, ao propor a criação, o aumento ou a extensão de uma prestação de seguridade social, se respeitado o preceito do $\$ 5^{\circ}$ do art. 195 , deve-se também indicar a correspondente fonte de custeio, o que pode diminuir a "vantagem" que se teria com a ampliaçáo da proteção, pois a criação de um tributo, muitas vezes, não é recebida de maneira positiva pela população. 
Também, o princípio deveria evitar decisóes generosas por parte do Poder Judiciário, mas, como já exemplificado, não tem sido óbice a milhares de decisões que tem afastado preceitos legais e ampliado a proteção, sem observância ao princípio em questão.

\section{Solidariedade}

A solidariedade sempre foi o fundamento da proteção social, efetivando-se em grupos menores, como a família, até grupos maiores, como a sociedade organizada, por meio do Estado. Nesse sentido, verifica-se que a solidariedade é um dos pilares do Estado brasileiro e um de seus objetivos, expresso no art. $3^{\circ}$, I, da Constituição.

No que tange à seguridade social, os artigos 194 e 195 da Constituição demonstram que a solidariedade é a base da proteção social brasileira. $\mathrm{O}$ caput daquele artigo estabelece que as açóes de seguridade social são de responsabilidade, tanto dos Poderes Públicos, quanto da sociedade, revelando a solidariedade no que tange à execução das ações protetivas. O caput do art. 195 preceitua que o financiamento da seguridade social é de responsabilidade de toda a sociedade.

O princípio da solidariedade desempenha papel fundamental na seguridade social, a qual, por ter um caráter universal, proporciona proteção a todos aqueles que estão em situação de necessidade.

\section{Financiamento da Seguridade Social}

A seguridade social compreende um conjunto integrado de açóes de iniciativa dos poderes públicos e da sociedade, destinadas a assegurar os direitos relativos à saúde, à previdência e à assistência social. Para garantir a citada proteção, a Constituição prevê meios de financiamento, cuja responsabilidade, conforme prevê o caput do art. 195, é de toda a sociedade, que o faz de forma direta e indireta.

A forma indireta é efetivada pela destinação de recursos do orçamento fiscal e pela parcela dos recursos dos concursos de prognósticos promovidos pelo Poder Público destinada à seguridade social ${ }^{7}$.

Verifica-se a destinação de recursos do orçamento fiscal, no art. 198, \$2º (em relação à saúde) e no art. 204, parágrafo único (em relação à assistência social), ambos da Constituição.

Já a forma direta é efetuada por meio das contribuiçóes de seguridade social, as quais tem seus pressupostos estabelecidos nos incisos do art. 195 e no art. 239, ambos da

7 Conforme PIERDONA, Zélia Luiza. Contribuiçōes para a seguridade social, São Paulo, LTr, 2003, p. 62. 
Constituição. Como regra geral, quem pode instituir as citadas contribuiçóes é a União, conforme caput do art. 149, combinado com o art. 195. A única exceção está prevista no art. $149, \$ 1^{\circ}$, que corresponde à competência dos Estados, Distrito Federal e Municípios para instituir contribuição previdenciária de seus servidores, para o financiamento dos Regimes Próprios de Previdência Social.

Além das contribuiçôes já pressupostas, a Constituição permite a instituição de outras fontes, no $\$ 4^{\circ}$ do art. 195. Emendas à Constituição também podem ser utilizadas para ampliar as fontes de financiamento, como foi o caso da CPMF, a qual teve autorização pelas EC nos. 12/1996, 21/1999, 37/2002 e 42/2003.

Também na forma direta de financiamento se inclui a possibilidade de o usuário ser chamado a participar diretamente do custeio, por meio do pagamento de serviços oferecidos pela seguridade social ou de parte deles, conforme se mencionou nos princípios da equidade na forma de participação do custeio e no da diversidade de bases de financiamento.

\section{4. Áreas Componentes da Seguridade Social}

$\mathrm{O}$ art. 194 da CF estabelece que a seguridade social compreende um conjunto integrado de açóes destinadas a assegurar os direitos relativos à saúde (arts. 196-200), à previdência social (arts. 201, 202 e 40) e à assistência social (arts. 203 e 204). Conforme mencionado acima, a seguridade social apresenta duas faces: em uma delas encontra-se a saúde, que, a partir da Constituição de 1988, foi universalizada, ou seja, destina-se a todos, independentemente de ser trabalhador ou dependente de trabalhador. A outra face inclui a previdência e a assistência social, as quais juntas efetivam o princípio da universalidade. Nesta face, a assistência social tem natureza subsidiária. Essa subsidiariedade dá-se sob um duplo aspecto: será subsidiária da previdência, na medida que se um cidadão for beneficiário da previdência, não o será da assistência, ao menos no que tange às prestaçôes pecuniárias, garantidoras de renda mínima. Além disso, será também subsidiária da proteção familiar, ou seja, da proteção privada, pois o Estado apenas deve atuar na ausência da proteção individual ou familiar.

A Constituição, no caput do art. 194, estabelece que as açôes são de iniciativa dos Poderes Públicos e da sociedade. Nesse sentido, quando menciona "Poderes Públicos", deve-se ter presente que o Estado brasileiro é uma federação. Em razão disso, as atribuiçôes relacionadas a cada uma das subáreas da seguridade social encontram-se definidas na Constituição.

Nesse sentido, o art. 23, II estabelece que a saúde e a assistência social são de competência administrativa comum de todos os entes da federação. Já em relação à previdência 
social, apenas a proteção dos servidores públicos titulares de cargos efetivos dos Estados, do Distrito Federal e dos Municípios são de competência administrativa dos mencionados entes federativos. O restante da proteção é de competência da União, tanto em relação a seus servidores, quanto no que tange ao Regime Geral de Previdência Social.

Feitas essas consideraçóes, passa-se a tratar, sinteticamente, cada umas das subáreas integrantes do sistema de proteção social.

\section{Saúde}

A Constituição de 1988 universalizou o acesso a saúde, tendo assim preceituado no art. 196: "a saúde é direito de todos e dever do Estado, garantido mediante políticas sociais e econômicas que visem à reduçáo do risco de doença e de outros agravos e ao acesso universal e igualitário às ações e serviços para sua promoção, proteção e recuperação". Assim, tem-se como características principais da saúde: a universalidade (direito de todos) e a igualdade de acesso às açóes e serviços de saúde. Sua efetivação deve ser efetuada por meio de políticas sociais e econômicas.

Em relação à saúde, a atribuição, conforme referido acima, é de todos os entes federativos. Isso está demonstrado no preceito do art. 198 da Constituição, que assim estabelece: "as açóes e serviços públicos de saúde integram uma rede regionalizada e hierarquizada e constituem um sistema único", organizado de forma descentralizada, com direção única em cada esfera de governo.

O referido dispositivo constitucional ainda prevê o atendimento integral, no qual serão priorizadas as atividades preventivas, sem prejuízo dos serviços assistenciais. Por fim, o enunciado estabelece a participação da comunidade, a qual revela a gestão democrática a que se refere o inciso VII do parágrafo único do art. 194 da Constituição. Assim, mesmo que o art. 198 não mencionasse a participação da comunidade, haveria a referida participação, em razão do princípio da gestão democrática.

Embora a saúde seja universal, no sentido de não estar mais limitada aos trabalhadores e seus dependentes, a ela se aplica também o princípio da seletividade. Nesse sentido, ressalta-se que mesmo que a Constituição não estabelecesse expressamente o citado princípio, haveria a implementação progressiva do princípio da universalidade, haja vista a disposição do item "1" do art. 20 do Pacto Internacional dos Direitos Econômicos, Sociais e Culturais ${ }^{8}$, o qual tem aplicação no Ordenamento Jurídico Brasileiro (Decreto 591/92).

8 1. Cada Estado Parte do presente Pacto compromete-se a adotar medidas, tanto por esforço próprio como pela assistência e cooperação internacionais, principalmente nos planos econômico e técnico, até o máximo de seus recursos disponíveis, que visem a assegurar, progressivamente, por todos os meios 
Os $\$ \$ 1^{\circ}$ a $3^{\circ}$ do art. 198 estabelecem preceitos relacionados à forma indireta de financiamento da saúde, na medida em que determinam a destinação de recursos dos orçamentos fiscais dos entes federativos à saúde, além das contribuiçôes de seguridade social, mencionadas na primeira parte do $\$ 1^{\circ}$ do art. 198.

Nos termos do art. 197 da Constituição, as açôes e serviços de saúde são de relevância pública, cabendo ao Poder Público sua regulamentação, fiscalização e controle. A execução pode ser feita diretamente pelo Poder Público ou por terceiros, neles incluindose pessoa física ou jurídica de direito privado.

Importante mencionar que a saúde, por ser uma área integrante da seguridade social, deve observar os preceitos dos arts. 194 e 195 da Constituição, que são normas dirigidas ao sistema de proteção social. Com isso, a responsabilidade na efetivação do direito à saúde não é exclusiva do Estado, já que, nos termos do caput do art. 194, as açóes de seguridade social são de iniciativa dos Poderes Públicos e da sociedade.

Por fim, “a assistência à saúde é livre à iniciativa privada” (art. 199), a qual poderá "participar de forma complementar do sistema único de saúde, mediante contrato de direito público ou convênio, tendo preferência as entidades filantrópicas e as sem fins lucrativos". Portanto, a Constituição também prevê a proteção privada à saúde, o que comprova, mais uma vez, que o Estado não é o unico responsável pela efetivação do direito à saúde.

$\mathrm{O}$ ordenamento infraconstitucional relativo à saúde tem suas normas básicas nas Leis no 8.080/1990 e no 9.656/1998.

\section{Previdência Social}

A previdência social é um direito dirigido aos trabalhadores e seus dependentes e tem por objetivo garantir recursos nas situaçóes em que eles não poderão ser obtidos pelos próprios trabalhadores. Com isso, a previdência garante a manutençáo do nível de vida do trabalhador, embora limitada a um determinado patamar de proteção.

Entretanto, é um direto que exige o cumprimento de um dever, na medida em que exige a contraprestação direta do segurado para que ele e/ou seus dependentes façam jus às prestações previdenciárias.

A Constituição prevê a previdência obrigatória e a complementar: a obrigatória inclui o Regime Geral de Previdência Social (art. 201) e os Regimes dos Servidores Públicos (art. 40). Aquele destina-se a todos os trabalhadores, exceto os servidores titulares de cargos

apropriados, o pleno exercício dos direitos reconhecidos no presente Pacto, incluindo, em particular, a adoção de medidas legislativas. 
efetivos, os quais são protegidos pelos Regimes Próprios, no caso de o ente federativo o ter instituído.

Assim, por meio da proteção obrigatória o Estado viabiliza a todos os trabalhadores o acesso à previdência, garantindo-lhes proteção nas situaçóes de necessidades elencadas no art. 201 da Constituição, como morte, idade avançada, invalidez etc.

A proteção previdenciária obrigatória apresenta limites, que inclusive pode ser o mesmo no Regime Geral e nos Regimes Próprios, haja vista as disposições do art. 40, \$14, da Constituição.

O art. 201 da Constituição estabelece os preceitos aplicáveis ao Regime Geral, o qual é aplicado a todos os trabalhadores, excluindo-se os servidores públicos titulares de cargos efetivos da União, dos Estados, do Distrito Federal e dos Municípios e de suas autarquias e fundações, aos quais é destinada a proteção prevista no art. 40. Ainda são excluídos os militares, conforme estabelece o inciso X, do art. 142 e os $\$ \$ 1^{\circ}$ e $2^{\circ}$ do art. 42 , todos da Constituição.

A previdência obrigatória tem como pressuposto o exercício de atividade remunerada e a contraprestação direta do segurado, por meio de contribuiçóes sociais. Portanto, tem natureza profissional/contributiva.

A Constituição ainda prevê a previdência complementar, no art. 202 e nos $\$ \$ 14$ a 16 do art. 40. Organizada de forma autônoma em relação à previdência obrigatória, a complementar é facultativa. Seu objetivo é permitir a continuidade do mesmo nível de vida do trabalhador ${ }^{9}$, especialmente quando seus rendimentos ultrapassam o teto de proteção da previdência obrigatória. As Leis Complementares 108/2001 e 109/2001 estabelecem normas dirigidas à previdência complementar.

O Regime Geral de Previdência Social é atribuição da União e, os Regimes Próprios dos Servidores Públicos, de cada um dos entes federativos. A previdência complementar é fiscalizada pela União.

\section{Assistência Social}

A assistência social é dirigida aos necessitados e o acesso à mencionada proteção independe de contribuição.

Segundo o Relatório Beveridge $e^{10}$, a assistência social deve atender as necessidades que não são cobertas pelo seguro (previdência social). Ainda segundo Beveridge, as necessidades deverão ser atendidas adequadamente, garantindo-se, assim, o nível de subsistências.

9 Segundo o Relatório Beveridge a previdência complementar atende às necessidades reais do trabalhador. BEVERIDGE, William. Seguro social y servicios afines: informe de Lord Beveridge, Madrid, Centro de Publicaciones del Ministerio de Trabajo y Seguridad Social, 1989, p. 240.

10 William Beveridge, Seguro social y servicios afines: informe de Lord Beveridge, cit., p. 237. 
Assim, por meio da assistência social é possível efetivar-se o princípio da universalidade, na medida que a previdência atende aos trabalhadores e, a assistência, os demais necessitados.

Possui previsão constitucional nos arts. 203 e 204, sendo regulada pela Lei Orgânica da Assistência Social (Lei 8.742/93).

A responsabilidade pela execução da assistência social é de todos os entes federativos, nos termos do art. 23, II, da Constituição.

O art. 204 da Constituiçáo, nos incisos I e II reafirma o preceito do inciso VII do parágrafo único do art. 194, o qual dispóe sobre a gestão democrática e descentralizada da seguridade social: o inciso I trata da descentralização e o II da gestão democrática.

Por fim, o parágrafo único do art. 204 faculta aos Estados e ao Distrito Federal vincular, em seus orçamentos, receitas tributárias à assistência social, especificamente, até cinco décimos por cento de sua receita tributária líquida, à programa de apoio à inclusão e promoção social.

\section{Conclusões}

Pelo exposto, verifica-se que o objetivo da seguridade social é proteger a todos os cidadãos, em todas as situaçóes de necessidade. Para tanto, a proteção social é efetivada por meio de três direitos sociais (saúde, previdência e assistência social), os quais devem ser analisados no sistema de proteção social instituído na Constituição de 1988 e não de forma isolada.

A falta de visão sistêmica tem sido uma constante, tanto pelos membros do Poder Legislativo, quanto do Poder Judiciário, o que tem gerado incoerências no sistema de seguridade social, as quais certamente comprometerão sua sustentabilidade futura, afetando, dessa forma, a equidade intergeracional.

Para evitar isso, os preceitos de qualquer uma das subáreas da seguridade social devem ser interpretados a partir dos princípios específicos aplicáveis a todas elas. Além disso, por se tratar de direitos sociais, exigem análise que considere a coletividade protegida, que considere, também, as futuras geraçóes e não somente os atuais protegidos.

\section{Referências}

BEVERIDGE, William Henri. Seguro social y serviços afines: informe de Lord Beveridge. Titulo Original: Social insurance and allied services. Madrid: Centro de Publicaciones del Ministerio de Trabajo y Seguridad Social, 1989.

BONAVIDES, Paulo. Curso de Direito Constitucional. 24 ed. São Paulo, Malheiros, 2009. 
OIT. Estabelecimento de normas de seguridade social em uma sociedade global, documento 2, p. 25 in http://www.ilo.org/public/spanish/protection/secsoc/downloads/ policy/policy2s.pdf.

PIERDONÁ, Zélia Luiza. Contribuiçôes para a seguridade social. São Paulo, LTr, 2003.

A proteção social na Constituição de 1988. Revista Internacional de Direito e Cidadania, v. 01, p. 237-249, 2008. 